\begin{tabular}{lcc}
\hline \multicolumn{3}{c}{ A N N A L E S } \\
UNIVERSITATIS MARIAE CURIE-SKŁODOWSKA \\
LUBLIN - POLONIA \\
VOL. XXIII, 2 & SECTIOK K \\
\hline
\end{tabular}

Uniwersytet Pedagogiczny w Krakowie

ANDRZEJ PIASECKI

Szanse i zagrożenia lokalnej demokracji w Polsce. Zarys problematyki ${ }^{1}$

Opportunities and threats of local democracy in Poland. An outline of the issues

\begin{abstract}
ABSTRAKT
Artykuł zawiera przegląd dotychczasowych doświadczeń administracji jednostek samorządu lokalnego w zakresie funkcjonowania demokracji bezpośredniej. Uwzględnia ewolucję tego zjawiska na przestrzeni 25 lat oraz jego systematykę. Obejmuje referenda obligatoryjne i fakultatywne, konsultacje społeczne, zebrania mieszkańców, inicjatywy obywatelskie oraz inne formy lokalnej demokracji bezpośredniej. Autor poddaje tytułowe zagadnienie naukowemu wartościowaniu, przedstawiając również możliwe rozwiązania ustrojowo polityczne.
\end{abstract}

Słowa kluczowe: demokracja, głosowania, władza, gmina, powiat, polityka, administracja

\title{
WSTĘP
}

Ponad 27 lat historii polskiej demokracji zawiera w sobie także wymiar lokalny. Jest on powiązany głównie z instytucjami i organizacjami samorządu terytorialnego. W tym obszarze można też wyodrębnić dodatkowy element, jakim jest demokracja bezpośrednia na poziomie gminy i powiatu. Na styku tych dwóch, jakże szerokich pojęć (demokracja bezpośrednia i samorząd terytorialny), mamy bogaty materiał

\footnotetext{
1 Artykuł powstał na bazie grantu Narodowego Centrum Nauki (nr projektu 2014/15/B/HS5/01866) „Demokracja bezpośrednia w Europie Środkowej i Wschodniej po 1989 roku. Wymiar formalnoprawny i praktyczny. Analiza politologiczna".
} 
do badań, który nawet tylko ograniczony do lokalnego wymiaru (czyli gminnego i powiatowego $)^{2}$ doczekał się już szerokiej literatury naukowej³ ${ }^{3}$.

W publikacjach naukowych omówiono: referenda, konsultacje społeczne, zebrania mieszkańców, inicjatywy obywatelskie oraz inne formy lokalnej demokracji bezpośredniej. Niektóre z nich wynikają z ustaw, inne są zapisane w statutach jednostek samorządowych. Przepisów odnoszących się do demokracji bezpośredniej jest coraz więcej i przybierają one bardzo zróżnicowany charakter. Wśród opracowań na ten temat dominuje opis, mniej jest wyjaśnien dotyczących badanego zjawiska. Dlatego niniejszy artykuł jest próbą wypełnienia tej niszy, aspirując zarazem do formy holistycznego zarysu dziejów polskiej demokracji bezpośredniej w gminach i powiatach. Taka publikacja wpisuje się w rozwój badań nad systemem politycznym Polski. Wiele wskazuje na to, że w najbliższych latach będziemy mieli do czynienia z dalszym rozwojem demokracji bezpośredniej na poziomie lokalnym i w związku z tym zasadne są pytania o szanse i zagrożenia, jakie niosą te procedury. Stosując metodę historyczną, a także wykorzystując analizę SWOT, autor zamierza dokonać oceny tytułowego zagadnienia, postara się też je skomentować i sformułować rekomendacje, które mogą być zastosowane w praktyce lokalnej działalności publicznej. W metodzie tej źródłami będą materiały empiryczne zgromadzone w trakcie własnych ${ }^{4}$ badań nad demokracją bezpośrednią oraz wiele aktów normatywnych, danych statystycznych, opracowań naukowych i publicystycznych. Pozostaje mieć nadzieję, że obszerna i zróżnicowana literatura przedmiotu uzasadni syntetyczne (z racji objętości artykułu) spojrzenie autorskie, a z drugiej strony zachęci do dalszych przyczynkowych analiz.

2 Dwie ustawy samorządowe (gminna i powiatowa) mówią o lokalnej wspólnocie samorządowej. W ustawie o samorządzie województwa znalazł się natomiast termin ,regionalna społeczność samorządowa”. Dla potrzeb tego artykuł zdecydowano się na normatywne ograniczenie pojęcia „lokalności”. Dlatego pod względem terytorialnym artykuł dotyczy wyłącznie polskich gmin, gmin na prawach powiatu oraz powiatów ziemskich.

3 Pełny przegląd literatury przedmiotu tytułowego zagadnienia wykracza poza skromne ramy tego artykułu. Są to m.in. dwie obszerne prace zbiorowe, które poniżej będą często przywoływane. Obydwie prace pokazują ogromny zakres badań nad lokalną demokracją bezpośrednią, prowadzonych w środowisku politologów: [Marczewska-Rytko, Michałowski 2012], [Dolnicki 2014].

4 W ocenach, komentarzach i rekomendacjach autor oparł się na materiale badawczym zaprezentowanym w kilkunastu publikacjach na temat lokalnego wymiaru demokracji bezpośredniej. Są to m.in.: książki Referenda lokalne w III RP, Wydawnictwo PWN, Warszawa 2005; Samorząd terytorialny $i$ wspólnoty lokalne, Wydawnictwo PWN, Warszawa 2009, oraz artykuły: Referenda lokalne w Polsce, „Samorząd Terytorialny" Warszawa 2004, nr 7-8; Demokracja bezpośrednia w Polsce lokalnej-błędny model, zła praktyka, „Studia Regionalne i Lokalne” 2005, nr 3 (21); Referenda lokalne w Polsce jako przejaw populizmu czy społeczeństwa obywatelskiego?, [w:] Populizm na przełomie XX i XXI wieku. Panaceum czy pułapka dla wspótczesnych społeczeństw?, M. Marczewska-Rytko (red.), Wydawnictwo Adam Marszałek, Toruń 2006; Direct democracy in Poland after 1989, „The Sejm Review” - Third special Edition 2007; Referenda lokalne - wymiar normatywny i empiryczny, [w:] Samorzadowe prawo wyborcze - wyzwania i dylematy, M. Stec, K. Małysa-Sulińska (red.), Wolters Kluwer, Kraków 2010; Twenty years of Polish direct democracy at the local level, Theo Schiller (ed.), Local Direct Democracy in Europe, VS: Verlag für Sozialwissenschaften, Wiesbaden 2011. 


\section{REFERENDA ODWOEAWCZE}

W III RP wspólnoty gminne musiały najwcześniej zmierzyć się właśnie z tą formą demokracji bezpośredniej. Wymienione w konsytuacji, wprowadzone do ustawy samorządowej już w 1990 r., implementowane dwiema ustawami [Ustawa o referendum gminnym z 11 października 1991 r.; Ustawa o referendum lokalnym z 15 września 2000 r.], referenda lokalne wymusiły na lokalnych działaczach samorządowych wiele doraźnych działań oraz zachowań uwzględniających potężną siłę polityczną, która stała za takim powszechnym głosowaniem. Jego obligatoryjny charakter (jak zaznacza ustawa) wskazywał, że tylko w ten sposób mieszkańcy mogą dokonać odwołania organu gminy. Wprawdzie w pierwszych trzech kadencjach samorządu możliwości odwołania dotyczyły tylko rady, ale gdy od 2002 r. zasada ta objęła również wójta, referenda te stały się najskuteczniejszym instrumentem oddziaływania mieszkańców na administrację lokalną. Początkowo znaczna ich część miała podłoże populistyczne i polityczne. Widoczne to było przy ogólnikowo sformułowanych zarzutach wobec władz administracyjnych (,niespełnienie obietnic wyborczych"). Bezskuteczność kiepsko przygotowanych referendów obnażała niska frekwencja wyborcza (w około 10\% przypadków głosowało mniej wyborców niż było podpisów pod inicjatywą referendalną). Jednak po uelastycznieniu progów frekwencji (od 2006 r.) coraz więcej było referendów, które można uznać za przejaw obywatelskiej troski o jakość zarządzania publicznego. Tak było w tych miastach (Gorzów Wielkopolski i Piotrków Trybunalski oraz Olsztyn), gdzie na prezydentach ciążyły zarzuty prokuratorskie. Podobnie należy ocenić skuteczne referenda w Łodzi i w Częstochowie, gdzie odwołanie prezydentów miast połączyło siły kilku środowisk i partii.

Wójtowie widzieli w tych referendach oczywiste zagrożenie dla swojej władzy. Niemal zawsze (bardziej lub mniej jawnie) zachęcali do bojkotu głosowania. W 2013 r. sam premier zasugerował to, broniąc prezydent stolicy [Zieliński 2014: 226]. Brakowało postaw otwartości i odwagi politycznej, które wymagałyby odwołania się do swoich zwolenników. Tylko w jednym wypadku (prezydenta Sopotu w 2009 r.) takie referendum zakończyło się wystarczającą frekwencją połączoną z akceptacją dla urzędującego lidera [Oficjalne wyniki sopockiego referendum]. Pokazało to jednak innym samorządowcom, że tzw. referenda odwoławcze mogą być nie tyle zagrożeniem co szansą. Dotyczy to również pozostałych form demokracji bezpośredniej.

Emocje związane z referendami odwoławczymi są największe, a próby ich ograniczenia ze strony przedstawicieli administracji samorządowej można uznać za systemowy przykład lobbingu elit. Wójtowie będą zapewne nadal odwoływali się do dyskretnej (lub jawnej) obstrukcji przy takich głosowaniach, ale wszelkie próby normatywnego ograniczenia możliwości ich odwoływania powinny być neutralizowane przez ekspertów i publicystów. W warunkach utrzymującej się dominacji monokratycznych organów wykonawczych w całym systemie samorządu gminnego, 
referendum w sprawie odwołania pozostaje jedynym skutecznym instrumentem nacisku i egzekucji ze strony lokalnego suwerena, jakim są mieszkańcy samorządowej wspólnoty. Biorąc więc pod uwagę wszystkie plusy i minusy tych referendów, należy je uznać za fundament lokalnej demokracji oraz skuteczny środek prakseologicznego nadzoru nad pracą lidera administracji gminy.

\section{REFERENDA W „WAŻNEJ SPRAWIE”}

Ta forma demokracji bezpośredniej doczekała się szerokiego orzecznictwa oraz innych interpretacji zakresu przedmiotowego „ważnej sprawy”. To trochę niefortunne sformułowanie ustawowe powinno być doprecyzowane w kwestii okoliczności tego, co może, a co nie może lub nie powinno być przedmiotem powszechnego głosowania w samorządowej wspólnocie. Pod dyskusję poddawany jest próg ważności takiego referendum, a wybitni eksperci (w tym prof. Jerzy Regulski) opowiadali się nawet za całkowitym zniesieniem progów frekwencyjnych. To właśnie ta bariera, podobnie jak przy innych referendach, najczęściej uniemożliwiała rozstrzygnięcie przedmiotowej kwestii w głosowaniu.

Referenda w ważnej sprawie były często podejmowane z inicjatywy mieszkańców, także w warunkach konfrontacji z polityką lokalnej administracji. Najbardziej efektowne było referendum (2014) w sprawie odrzucenia inicjatywy władz Krakowa zmierzającej do organizacji w tym mieście igrzysk zimowych. Mobilizacji ruchów miejskich sprzyjały przeprowadzone w dniu referendum wybory do Parlamentu Europejskiego. Do skuteczności głosowania przyczyniła się też skala błędów popełniona przez administrację samorządową Krakowa przy wstępnym planowaniu tych igrzysk oraz wyjaśnianiu ich znaczenia mieszkańcom [Kraków przeciwko igrzyskom].

Administracja lokalna niekiedy wywiera nacisk na grupę inicjatywną, a częściej na radnych, aby w ten właśnie sposób rozstrzygnąć problemy (w świetle ustawy referendum to może zainicjować $10 \%$ wyborców lub uchwała rady). Taka sytuacja ma miejsce, gdy trzeba zrealizować kontrowersyjną inwestycję (spalarnie śmieci) albo zlikwidować szkołę. Metoda vox populi może świadczyć o próbie pozyskania poparcia dla trudnych decyzji, ale może też być przejawem asekuracji ze strony urzędników szukających argumentów w niewygodnej sytuacji. Należy jednak pamiętać, że decyzji wyrażonej w referendum nie może zmienić uchwała rady. Taką interpretację ustawy już w 1997 r. zaprezentował Naczelny Sąd Administracyjny ${ }^{5}$, co wzmacnia całą lokalną demokrację bezpośrednią w relacjach z organami władzy. Stanowi to zarazem szansę dla aktywizacji obywatelskiej,

5 Sąd uznał, że referendum gminne jest jedną z władz jednostki samorządowej i to władzą najwyższą. W ten sposób instytucja referendum przejmowała w określonej sprawie kompetencje zarządu i rady. A ustawowe zastrzeżenie określonych materii do „wyłącznej właściwości rady nie skutkuje w stosunku do mieszkańców wyrażających swą wolę w drodze referendum”. Fragment orzeczenia za: [Izdebski 2004: 138]. 
wzmacnia podmiotowość ruchów miejskich i sprzyja klarownemu rozstrzygnięciu wielu lokalnych dylematów.

Jednocześnie referenda w ważnej sprawie, zbyt często organizowane, groziłyby populizmem, paraliżem pracy administracji lokalnej oraz wzmocnieniem asekuracji w działalności wójtów. Dlatego najważniejszą rekomendacją byłoby tu umiarkowane korzystanie z tej formy demokracji bezpośredniej. Doświadczenia wskazują, że referenda te nie są jednak nadużywane.

Przykład referendum krakowskiego oraz nowe formy inicjatyw lokalnych (np. ruchy miejskie) wskazują, że możemy się spodziewać częstszych referendów w ważnej spawie. Do tej pory odbyło się około stu takich głosowań. Wzrośnie też ich skuteczność. Gdyby więc jeszcze uelastycznić frekwencję dla ważności takiego głosowania, to można oczekiwać, iż te fakultatywne (w świetle ustawy) referenda staną się ważnym elementem lokalnej rzeczywistości politycznej. Zwłaszcza przy podejmowaniu przez władze strategicznych i trudnych decyzji.

\section{REFERENDUM W SPRAWIE SAMOOPODATKOWANIA}

Jest to najrzadziej stosowane referendum, ale najczęściej inicjowane przez radę gminy. Zaangażowanie w nie pracowników samorządowych powoduje, że referenda te są najskuteczniejsze, jeśli już władze zdecydują się na ich przeprowadzenie. Okazuje się, że w tej pozornie trudnej kwestii (nałożenie dodatkowej opłaty na mieszkańców) wszechstronne wyjaśnienie przedmiotu sprawy, rzeczowa argumentacja, użyteczny cel - wszystko to pomaga pokonać próg wysokiej frekwencji (30\%) i akceptacji (2/3 głosów na ,tak”).

Nieliczne przykłady referendów w sprawie samoopodatkowania (w ciągu 25 lat przeprowadzono ich ok. 50) mogą w większości stanowić model rozwiązywania wielu problemów z zakresu zarządzania publicznego. Zagrożeniem jest tu jednak ryzyko polityczne co do wyniku takiego głosowania. Jego efekty oprócz korzyści mogą przynieść też straty, a tego urzędnicy (zwłaszcza wójtowie) pragną uniknąć. Wiadomo, że realia administracyjne (nie tylko lokalne) częściej premiują kunktatorstwo, asekuranctwo, proceduralność niż innowacje, otwartość, dynamikę. Dlatego trudno liczyć, aby referenda w sprawie samoopodatkowania stały się powszechnym sposobem na dopełnianie budżetu gmin. Choć oczywiście pozostają szansą na rozwiązanie palących problemów lokalnych na bazie partycypacji obywatelskiej.

Referenda w sprawie samoopodatkowania były najczęściej realizowane przez władze lokalne jako przejaw polityki ekologicznej. Niekiedy odbywało się to jednak w referendum fakultatywnym (,w ważnej sprawie”) i dotyczyło budowy spalarni śmieci. Niemniej jednak potoczna nazwa ,referendum śmieciowe” częściej pojawia się w przypadku obligatoryjnego referendum w sprawie samoopodatkowania. Pierwsze takie referendum odbyło się w podpoznańskiej gminie Pobiedziska, gdzie 
przeprowadzono je w 1991 r. z inicjatywy mieszkańców. Frekwencja wyniosła 56\%, a 76\% głosów ważnych było za opodatkowaniem [Janus 2004: 181].

$\mathrm{Na}$ zmniejszenie znaczenia tej formy demokracji bezpośredniej wpłynęła też nieprecyzyjność zapisu ustawy oraz jeszcze mniej spójne orzecznictwo sądowe. Już w samej nazwie tego referendum mamy delikt normatywny. Podatki bowiem to domena ustawodawcy, a nakładając je, gminny organ stanowiący musi się poruszać w określonych granicach. Żaden inny podmiot nie ma prawa nakładać nowych podatków, chyba że chodzi o „dobrowolne świadczenie”. Ale wtedy nie można mówić o obligatoryjności takiej opłaty, co tym samym osłabia jej ściągalność, egzekucję itd. [Olejniczak-Szałowska 2002: 117]. Dla władz lokalnych takie bariery najbardziej determinują wstrzemięźliwość wobec odwoływania się do tych referendów.

\section{KONSULTACJE SPOŁECZNE}

O ile teoria i praktyka referendów zakłada ich wiążący charakter (tzn. podjęta $\mathrm{w}$ głosowaniu decyzja ma charakter obligatoryjny dla organów władzy), o tyle w przypadku konsultacji mamy do czynienia niejako z definicji z fakultatywnością. Czyli wynik konsultacji nigdy nie może być traktowany jako prawne zobowiązanie dla władz, co z założenia niesie ze sobą zagrożenie marginalizacji tej formy demokracji bezpośredniej. Jednocześnie obligatoryjne jest przeprowadzanie konsultacji, a pakiet spraw, których one dotyczą, ulega sukcesywnemu poszerzeniu. W praktyce konsultacje społeczne są obecnie najbardziej dynamicznie rozwijającą się formą demokracji bezpośredniej. Wynika to m.in. z konieczności zapewnienia partycypacji obywatelskiej (choćby przez konsultacje) przy aplikacji o środki unijne, a także $\mathrm{z}$ aktywizacji społecznej.

Od momentu restytucji samorządu terytorialnego przeprowadzenie konsultacji było obligatoryjne przy tworzeniu, łączeniu lub znoszeniu gminy (jej nazwy i siedziby władz) oraz przed utworzeniem jednostki pomocniczej gminy. Po nowelizacji z 1996 r. dodano także, ,inne ważne dla gminy sprawy” [Ustawa z dnia 2 lutego 1996 r. o zmianie ustawy o samorządzie terytorialnym]. Zasady i tryb ich przeprowadzania mogły zostać określone w statucie gminy lub w uchwałach rady. Kolejne nowelizacje ustaw samorządowych z 11 kwietnia 2001 r. oraz z 26 maja 2011 r. poszerzały zakres przedmiotowy konsultacji (o kwestie granic jednostek pomocniczych gminy). W tej ostatniej nowelizacji wcześniejsze konsultacje „W sprawie granic” zostały w praktyce podniesione do rangi nowego rodzaju referendum, w którym podmiotem inicjującym mogą być mieszkańcy gminy.

Konsultacje społeczne przeprowadzono również w powiatowej wspólnocie samorządowej. Dotyczy to m.in. kwestii połączenia miasta na prawach powiatu z powiatem mającym siedzibę w tym mieście lub utworzenia powiatu, w którego skład wejdzie miasto na prawach powiatu [Stahl, Jaworska-Dębska 2010: 87-88]. Jednak praktyka administracyjna, podobnie jak w przypadku referendów, najmoc- 
niej wiąże konsultacje z działalnością urzędów gmin. Tzw. „ważne sprawy” będące przedmiotem konsultacji są często dookreślane w statutach albo w uchwałach rad. Standardowo dotyczy to kwestii planowania przestrzennego, zmiany nazwy ulic, kontrowersyjnych inwestycji, likwidacji palcówek, uchwalania statutów jednostek pomocniczych gminy. Z badań przeprowadzonych w latach 2010-2011 wynika, że konsultacje społeczne przeprowadzano w 87\% gmin wiejskich [Węglarz 2013: 139]. W wypadku miast było to ponad $90 \%$. To efekt większej liczby inwestycji, które takowych konsultacji częściej wymagają. Jednocześnie wyniki badań sugerują, że administracja samorządowa odwołuje się do konsultacji społecznych wtedy, gdy jest to niezbędne lub wymuszone normatywnie.

Najwięcej kontrowersji wywołują formy konsultacji, czego przejawem jest orzecznictwo sądów administracyjnych [Wyrok WSA w Łodzi z dnia 29 października 2009 r.; Wyrok WSA w Łodzi z dnia 29 marca 2010 r.]. Władza lokalna próbuje niekiedy sprowadzić je do kwestii informacyjnych, uznając za wystarczające np. rozesłanie projektu danej uchwały do rad osiedla. Nie ma to wówczas charakteru powszechnego. Tymczasem istotą konsultacji jest umożliwienie przez administrację wyrażenia opinii bezpośrednio wszystkim mieszkańcom, ich omówienie i w ten sposób właśnie skonsultowanie. Konsultacje społeczne nie mogą też przybierać charakteru referendum, nawet jeśli ich formą jest głosowanie powszechne, którego wynik nigdy nie będzie obligatoryjną normą. O tej oczywistej zasadzie warto przypomnieć w kontekście prób podejmowanych przez inicjatorów konsultacji, wywarcia presji na władze przez np. jednomyślną opinię uczestników konsultacji w danej sprawie. Zarazem organy władzy lokalnej (rady, wójtowie) mogą być oskarżane o ignorancję i arogancję, postępując wbrew jednolitemu stanowisku konsultowanych mieszkańców. Ale konsekwencje takiej postawy mają już tylko polityczne, a nie prawne znaczenie.

Na przełomie 2016 i 2017 roku przykładem zagrożeń, które stoją za lekceważeniem wyników konsultacji, była sprawa poszerzenia granic Opola wbrew opinii przygniatającej większości członków wspólnoty lokalnej. W efekcie grupa radykalnie nastawionych mieszkańców gmin podjęła głodówkę [Głodówka pod Opolem zaostrzona]. Jednocześnie konflikt ten ujawnił problemy polityczne i narodowościowe, których rozwiązanie mogło nastąpić po uwzględnieniu konsultacji społecznych. W jeszcze większym stopniu tzw. wielkiej polityki dotyczyła kwestia referendum granicznego w Warszawie, które zainicjowali radni stolicy, chcąc w ten sposób zablokować zmiany ustroju miasta stołecznego. Na początku 2017 r. wojewoda zaskarżył tę decyzję do sądu [Kłopotliwe referendum].

\section{INNE FORMY DEMOKRACJI BEZPOŚREDNIEJ W GMINIE}

W ramach jednostek pomocniczych gminy (JPG) podstawową formą demokracji bezpośredniej jest zebranie mieszkańców. Większość regulacji normatywnych dotyczących JPG powinna znajdować się w statutach gminy, dlatego trudno okre- 
ślić jednoznacznie, w jakim stopniu zebranie mieszkańców sołectwa, osiedla (itp.) może korespondować z bieżącą pracą administracji lokalnej. Na pewno dotyczy to najmniejszych gmin, jest też związane z konsultacjami. Ustawowo nadzór nad JPG pełnią organy gminne (rada, wójt). Ich partnerem ze strony JPG jest najczęściej sołtys wybierany przez uczestników zebrania wiejskiego. W tym miejscu warto zaznaczyć, że sołtys jako funkcjonariusz publiczny w ostatnich latach zmienił swoje oblicze, w sensie normatywnym i empirycznym. Jego rolę w relacjach z władzą lokalną wzmacniają wszystkie formy lokalnej demokracji bezpośredniej oparte na JPG (co wyrażają już ustawy i akty prawa miejscowego). Nie bez znaczenia jest też fakt wizerunkowego odejścia od schematu kabaretowego „sołtysa Kierdziołka” w kierunku profesjonalnego lidera, często z wysokimi kwalifikacjami, zawsze posiadającego silną legitymację wyborców. Liczy się też wzrost liczby kobiet pełniących tę funkcję, ludzi młodych, przedstawicieli różnych mniejszości (narodowych, religijnych, seksualnych) [Grzebałkowska 2011]. Potencjał sołtysów już dawno został dostrzeżony przez naukowców [Ptak 2012; Bondyra, Wojtkowiak 2013] i polityków, o czym świadczy m.in. działalność posła (senatora) Ireneusza Niewiarowskiego, który w 1994 r. założył w Koninie Krajowe Stowarzyszenie Sołtysów.

Tworząc miejscowe prawo dla JPG oraz decydując o finansowych możliwościach jednostki pomocniczej, władze gminy mają pozycję dominującą w stosunkach z JPG. Choć w tym wypadku podstawy demokracji bezpośredniej chronią mieszkańców JPG przed nadmierną ingerencją władz lokalnych. Przekonał się o tym m.in. wójt gminy Czermin (woj. wielkopolskie), który zorganizował zebranie wiejskie celem wyboru nowego sołtysa. Nie powiadomił jednak dotychczas urzędującego sołtysa o celu zwołania takiego zebrania, co przewidywał statut. Stało się to podstawą do podważenia legalności podjętych wtedy decyzji [Kaczorowski 2012].

Zebrania mieszkańców są niekiedy traktowane jako okazja do konsultacji. Ustawa daje tutaj dużą swobodę organom gminy. Jednak w ostatnich latach widoczna jest ewolucja tej formy demokracji bezpośredniej w kierunku powiązania uczestnictwa z finansami. Sygnałem tego są efekty ustawy z 20 lutego 2009 r. o funduszu sołeckim oraz procedury związane $z$ budżetem partycypacyjnym ${ }^{6}$. Wspomniany fundusz powstaje przez wydzielenie z budżetu uchwałą rady gminy. Następuje to w wyniku inicjatywy zebrania wiejskiego, które wskazuje wójtowi cele do realizacji. Jednak organ wykonawczy gminy może odmówić takiego wniosku, wtedy o jego losie decyduje rada gminy. Oceniając postawę władz lokalnych wobec tej formy demokracji bezpośredniej, warto przywołać ustalenia kontroli przeprowadzonej przez NIK w 2012 r. Wynika z niej, że głównym powodem uchybień w funkcjonowaniu funduszu jest nieudolność wójtów [Najwyższa Izba Kontroli 2012]. To z pewnością największe zagrożenie dla wzmocnienia rangi zebrania wiejskiego. Jak w wielu innych sprawach tak i tutaj decydujące znaczenie ma jakość kadr.

6 Ustawa została znowelizowana 21 lutego 2014 r. Dz.U. 2014, poz. 301. 
Z kolei budżet partycypacyjny w praktyce pojawił się w Polsce od 2011 r. (po raz pierwszy w Sopocie) i jest związany z nowymi formami aktywności lokalnej, które reprezentują struktury Lokalnych Grup Działania ${ }^{7}$ oraz inne mniej formalne ruchy miejskie, które można traktować jako inkubatory kapitału społecznego. Władze lokalne przez wydzielenie nieznacznej części budżetu (zazwyczaj ok. 1\%) przeprowadzają różnego rodzaju konsultacje wokół przeznaczenia tych środków. Mieszkańcy opowiadają się za jakimś projektem lub zgłaszają go sami, a nawet deklarują współudział w jego realizacji przez świadczenia pieniężne lub rzeczowe. Podstawą normatywną jest tu statut gminy, a ustawowe ramy wyznaczono m.in. nowelizacją ustawy o działalności pożytku publicznego i wolontariacie [Ustawa z dnia 24 kwietnia 2003 r. o działalności pożytku publicznego i wolontariacie].

Praktyka pokazuje, że administracja w większym stopniu angażuje się w fundusz sołecki oraz budżet partycypacyjny w roku wyborczym (2010 i 2014). W oficjalnych wypowiedziach pracowników samorządowych widoczny jest typowy „urzędowy optymizm", pojawiały się też wypowiedzi bardziej krytyczne (prezydenci Krakowa, Lublina, Rzeszowa). Entuzjazm dla budżetów partycypacyjnych wykazują działacze ruchów miejskich [Kongres Ruchów Miejskich] oraz eksperci [Szuber-Bednarz 2015: 736]. Wśród naukowców oraz publicystów również zdarzają się opinie negatywne [Majcherek 2015].

Wspomniana nowelizacja ustawy o działalności pożytku publicznego i wolontariacie wzmocniła kolejną formę demokracji bezpośredniej, z którą musi się zmierzyć władza lokalna. To obywatelska inicjatywa uchwałodawcza, która coraz częściej jest uwzględniana w statutach gmin [Miruć 2010: 33]. Określają one zwykle liczbę wyborców, których podpisy muszą uruchamiać taką inicjatywę. We Wrocławiu i w Płocku taki projekt wymaga 3 tys. podpisów, a w Warszawie już 15 tys. W innych miastach ten próg jest bardzo zróżnicowany. W Przemyślu wymaganych jest 1000 podpisów, w Otwocku 500, w Szczecinie 400, w Radlinie 300, w Głuszycy 200, w Toruniu 150, w Chełmży 100, w Puszczykowie, Tomaszowie Mazowieckim i w Dzierżoniowie po 50. W gminach wiejskich progi te są również zróżnicowane: w gminie Babice wymagano 250 podpisów, w Tyszowcach 50, w Główczycach 5 proc. W innych gminach (Tolkmicko, Ropa) statuty nie określają takich progów, ale wymieniają np. obok instytucji, organizacji społecznych, politycznych, zawodowych, samorządowych, stowarzyszeń inne „,zorganizowane grupy”. W 2010 r. według szacunkowych obliczeń obywatelska inicjatywa uchwałodawcza funkcjonowała w ponad stu gminach i w kilku powiatach [Piasecki 2010 a: 87-108].

7 Na temat LGD wiele badań przeprowadziła dr Monika Turek, zamieszczając wyniki w swej dysertacji Obszary wiejskie i instrumenty ich rozwoju w ramach Wspólnej Polityki Rolnej w Polsce od 2004 r., Kraków 2014. 


\section{ZAKOŃCZENIE}

Omówione powyżej przykłady demokracji bezpośredniej nie wyczerpują form tej instytucji, które występują w lokalnych wspólnotach. Demokracja deliberatywna, e-demokracja, demokracja komunikacyjna [Dobek-Ostrowska, Wiszniowski 2001: 25], a także demokracja hybrydowa (łącząca elementy demokracji przedstawicielskiej, partycypacyjnej, bezpośredniej) [Rajca 2014: 142] w wydaniu lokalnym ma wiele przejawów trudnych do usystematyzowania. Nowe technologie informacyjne i komunikacyjne stwarzają możliwość permanentnej debaty [Porębski 2012], w efekcie w wielu krajach europejskich administracja lokalna odwołuje się do innowacyjnych metod zarządzania z pogranicza demokracji bezpośredniej, jak np. conssus coference (konferencje konsensusowe), planing cell (komórki planowania), technological panels (panele technologiczne).

Polacy są zainteresowani rozwojem lokalnej demokracji bezpośredniej. Badania przeprowadzone w 2011 r. wskazują, że tylko 17\% uczestniczyło w jakichkolwiek konsultacjach społecznych, ale aż 57\% deklaruje chęć uczestniczenia w nich, a 81\% chce zostać wysłuchana, nawet jeśli miałoby to oznaczać wydłużenie czasu realizacji inwestycji lub podjęcia decyzji. W takim samym procencie ankietowani uważali, że potrzebne są zmiany form przeprowadzania konsultacji. 82\% opowiadało się za wprowadzeniem ,interpelacji obywatelskiej”, oznaczającej konieczność wyjaśnienia przez administrację konkretnej sprawy będącej przedmiotem dyskusji na forum samorządowego organu stanowiącego [Kloc 2014: 94]. Eksperci proponują wprowadzenie do statutów, a nawet do ustaw instytucji ,samorządowego wysłuchania publicznego" [Marchaj 2014].

To właśnie takie oczekiwania i ekspertyzy spowodowały podjęcie przez Kancelarię Prezydenta RP prac nad nową ustawą wzmacniającą partycypację obywatelską w pracy lokalnej administracji. Projekty te nie doczekały się jednak finału legislacyjnego, a wybory prezydenckie i parlamentarne w 2015 r. zmieniły realia polityczne dla tych inicjatyw ${ }^{8}$. Mimo to szanse i zagrożenia, które niesienie ze sobą demokracja bezpośrednia w lokalnej rzeczywistości, regularnie wywołują polemiki publicystów i naukowców ${ }^{9}$. W'śród wymienionych już w niniejszym artykule pozytywnych możliwości wykorzystania demokracji bezpośredniej znawcy problematyki szczególnie podkreślają znaczenie Internetu, demokracji deliberatywnej, glokalizacji. Z kolei zagrożenia są związane z hybrydowym populizmem, osłabieniem demokratycznych instytucji w wielu krajach oraz ze skutkami manipulacji w wirtualnej rzeczywistości.

8 W 2011 r. Kancelaria Prezydenta RP zakończyła prace nad projektem ustawy o wzmocnieniu udziału mieszkańców w działaniach samorządu terytorialnego, który po konsultacjach przygotowano w wersji ustawy o współdziałaniu w samorządzie terytorialnym na rzecz rozwoju lokalnego i regionalnego (skierowana do Sejmu 30 sierpnia 2013 r.).

9 M.in. polemika: A. Piasecki, Referenda to też samorządność, www.krakow.wyborcza.pl (dostęp: 3.01.2017). 


\section{BIBLIOGRAFIA}

Bondyra, K., Wojtkowiak, M. 2013. Demokracja bezpośrednia w Polsce. Solectwa wobec zmiany społecznej, [w:] Wspótczesna demokracja bezpośrednia. Dialog polsko-szwajcarski, B. Wiśniewska-Paź (red.), Wydawnictwo Aureus, Kraków.

Dobek-Ostrowska, B., Wiszniowski, R. 2001. Teoria komunikowania publicznego i politycznego, Wydawnictwo UWr, Wrocław.

Dolnicki, B. (red.) 2014. Partycypacja społeczna w samorzadzie terytorialnym, Wolters Kluwer, Warszawa.

Encyklopedia samorządu terytorialnego. Dla każdego, cz. 1: Ustrój, M. Stahl, B. Jaworska-Dębska (red.), Wydawnictwo Difin, Warszawa 2010.

Głodówka pod Opolem zaostrzona, www.newsweek.pl 4.01.2017.

Grzebałkowska, M. 2011. Soltys ma chlopaka, „Gazeta Wyborcza” 9.08.

Izdebski, H. 2004. Samorzad terytorialny. Podstawy ustroju i działalności, Lexis Nexis, Warszawa.

Janus, A. 2004. Polityczna partycypacja lokalna wyborcza i referendalna, [w:] Samorzad lokalny w Polsce. Społeczno-polityczne aspekty funkcjonowania, S. Michałowski, A. Pawłowska (red.), Wydawnictwo UMCS, Lublin.

Kaczorowski, A.W. 2012. Jak wójt usuwat soltysa, „Gazeta Sołecka” 25.02.

Kloc, E. 2014. Udział mieszkańców w stanowieniu prawa przez organy samorzadu terytorialnego - dobre prawo czy zludna iluzja, [w:] Partycypacja spoteczna w samorzadzie terytorialnym, B. Dolnicki (red.), Wolters Kluwer, Warszawa.

Klopotliwe referendum, WWW.fakty.interia.pl (dostęp: 2.03.2017).

Kongres Ruchów Miejskich, WWW.kongresruchowmiejskich.pl (dostęp: 3.11.2015).

Kraków przeciwko igrzyskom, www.krowoderska.pl (dostęp: 2.11.2015).

Majcherek, J. 2015. Odcienie populizmu, „Gazeta Wyborcza” 22.05.

Marchaj, R. 2014. Wystuchanie publiczne jako forma udziału wspólnoty lokalnej w procesie stanowienia prawa na szczeblu samorzadu terytorialnego, [w:] Partycypacja spoleczna w samorzadzie terytorialnym, B. Dolnicki (red.), Wolters Kluwer, Warszawa.

Marczewska-Rytko, M., Michałowski, S. (red.) 2012. Demokracja bezpośrednia w samorzadzie terytorialnym, Wydawnictwo UMCS, Lublin.

Miruć, A. 2010. Obywatelska inicjatywa uchwałodawcza, „Samorząd Terytorialny”, nr 1-2.

Najwyższa Izba Kontroli. 2012. Informacja o wynikach kontroli. Funkcjonowanie funduszy sołeckich, Gdańsk.

Oficjalne wyniki sopockiego referendum, gazeta.pl 18.05.2009.

Olejniczak-Szałowska, E. 2002. Referendum lokalne w świetle ustawodawstwa polskiego, Wydawnictwo Difin, Warszawa.

Pawlak, A., Guzik, P. 2017. Chodzi o pracę i o pole, „Gazeta Wyborcza” 5-6.01.

Piasecki, A. 2004. Referenda lokalne w Polsce, „Samorząd Terytorialny”, nr 7-8.

Piasecki, A. 2005. Demokracja bezpośrednia w Polsce lokalnej-błędny model, zła praktyka, „Studia Regionalne i Lokalne", $\mathrm{nr} 3$ (21).

Piasecki, A. 2005. Referenda lokalne w III RP, Wydawnictwo PWN, Warszawa.

Piasecki, A. 2006. Referenda lokalne w Polsce jako przejaw populizmu czy społeczeństwa obywatelskiego?, [w:] Populizm na przełomie XX i XXI wieku. Panaceum czy pulapka dla wspótczesnych społeczeństw?, M. Marczewska-Rytko (red.), Wydawnictw Adam Marszałek, Torun.

Piasecki, A. 2007. Direct democracy in Poland after 1989, „The Sejm Review” - Third special Edition.

Piasecki, A. 2009. Samorząd terytorialny $i$ wspólnoty lokalne, Wydawnictwo PWN, Warszawa.

Piasecki, A. 2010 a. Inicjatywa obywatelska w praktyce politycznej III RP, „Państwo i Społeczeństwo”, nr 2.

Piasecki, A. 2010. Referenda lokalne - wymiar normatywny i empiryczny, [w:] Samorzadowe prawo wyborcze - wyzwania i dylematy, M. Stec, K. Małysa-Sulińska (red.), Wolters Kluwer, Kraków.

Piasecki, A. 2011. Twenty years of Polish direct democracy at the local level, [w:] Local Direct Democracy in Europe, Th. Schiller (red.), VS, Verlag für Sozialwissenschaften, Wiesbaden. 
Piasecki, A. Referenda to też samorzadność, www.krakow.wyborcza.pl (dostęp: 3.01.2017).

Porębski, L. 2012. Debata lokalna jako środek idei demokracji bezpośredniej, [w:] Demokracja bezpośrednia w samorzadzie terytorialnym, M. Marczewska-Rytko, S. Michałowski (red.), Wydawnictwo UMCS, Lublin.

Ptak, A. 2012. Wybory soltysów i rad soteckich. W poszukiwaniu prawidet rywalizacji wyborczej w organach pomocniczych samorzadów gmin wiejskich, „Studia Regionalne i Lokalne”, nr 3.

Rajca, L. 2014. Local governance a partycypacja obywateli, [w:] Europejskie modele samorzadu terytorialnego. Stan obecny i perspektywy, J. Wojnicki (red.), Oficyna Wydawnicza ASPRA-JR, Warszawa.

Szuber-Bednarz, E.T. 2015. Budżet partycypacyjny a zasada jawności działania samorzadu terytorialnego, [w:] Jawność w samorządzie terytorialnym, B. Dolnicki (red.), Wolters Kluwer Warszawa.

Turek, M. 2014. Obszary wiejskie i instrumenty ich rozwoju w ramach Wspólnej Polityki Rolnej w Polsce od 2004 r., Kraków.

Ustawa o referendum gminnym z 11 października 1991 r., Dz.U. 1991, nr 110, poz. 473.

Ustawa o referendum lokalnym z 15 września 2000 r., Dz.U. 2000, nr 88, poz. 985.

Ustawa z dnia 2 lutego 1996 r. o zmianie ustawy o samorządzie terytorialnym, Dz.U. 1996, nr 58, poz. 261.

Ustawa z dnia 24 kwietnia 2003 roku o działalności pożytku publicznego i wolontariacie, Dz.U. 2010, nr 234, poz. 1536.

Węglarz, B. 2013. Ewolucja demokracji bezpośredniej w Polsce po 1989 r., Księgarnia Akademicka, Kraków.

Wyrok WSA w Łodzi z dnia 29 marca 2010 r., I IISA/Łd 104/10. LEX nr 577295.

Wyrok WSA w Łodzi z dnia 29 października 2009 r., III SA/Łd 404/09. Lex nr 528480.

Zieliński, E. 2014. Demokracja lokalna w Polsce, [w:] Demokracja lokalna w państwach Europy, I. Bokszczanin, A. Mirska (red.), Dom Wydawniczy „Elipsa”, Warszawa.

\section{OPPORTUNITIES AND THREATS OF LOCAL DEMOCRACY IN POLAND AN OUTLINE OF THE ISSUES}

Abstract: The following article includes an overview of the past experiences of the local governments' administration units in regard to direct democracy. It takes into account the evolution of this phenomenon in the past 25 years and its classification. It considers mandatory and optional referendums, public consultations, meetings of residents, civic initiatives and other forms of local participatory democracy. The author examines the issues presented in the title of this article while also evaluating possible systemic and political solutions to those issues.

Keywords: democracy, voting, government, municipality, district, politics, administration

\section{BIOGRAM}

Andrzej Piasecki, profesor dr hab., kierownik Katedry Samorządu i Zarządzania w Instytucie Politologii Uniwersytetu Pedagogicznego w Krakowie. Zajmuje się głównie samorządem terytorialnym, administracją publiczną, polityką regionalną, komunikacją społeczną, zarządzaniem i organizacją, systemem wyborczym, marketingiem politycznym. Więcej na: www.andrzejpiasecki.pl. Kontakt e-mail: prof. piasecki@gmail.com. 